\title{
Impression Management in the Sharing Economy: Understanding the Effect of Response Strategy to Negative Reviews
}

\author{
Complete Research
}
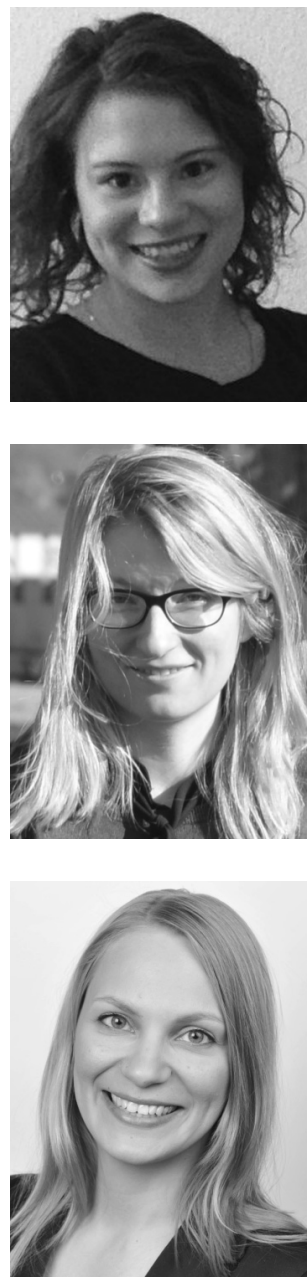

Olga Abramova, Hanna Krasnova, Tetiana Shavanova, Andrea Fubrer and Peter Buxmann

Sharing Economy, Airbnb, Online Reviews, Response

Sharing Economy, Airbnb, Online Bewertungen, Antwort

Recognizing the harmful effect of negative reviews on the reputation of the hosts as well as a subjective nature of the travel experience judgements, accommodation sharing platforms, like Airbnb, have introduced the response option, empowering hosts with the voice to deny, present an excuse, or at least apologize for the subject of the criticism. However, the effects of different response strategies on the impression of guests regarding the host and, above all, guests' willingness to rent a specific accommodation in the sharing setting remain unclear. To fill this gap, this study focuses on understanding the impact of different response strategies utilizing experimental methods. Our investigation shows that when the subject of complaint is controllable by a host, only the "confession / apology" strategy can improve the impression of guests regarding the host and enhance guests' willingness to rent, compared to the absence of response. However, when the subject of criticism is beyond the control of the host, both "confession / apology" and "excuse" have positive influence on the impression and also guests' willingness to rent. At the same time, "denial" strategy appears ineffective in both controllable and uncontrollable contexts we tested.

Als Folge der schädlichen Effekte negativer Berichte auf den Ruf eines Gastgebers sowie der Subjektivität der Reiseberichte auf Peer-toPeer Plattformen, wie Airbnb, wurde für die Gastgeber eine Antwortoption eingeführt und damit die Möglichkeit auf den Kritikpunkt zu reagieren (ablehnend, rechtfertigend oder entschuldigend). Dennoch bleiben die Auswirkungen verschiedener Antwortstrategien des Gastgebers auf die Wahrnehmung potenzieller Gäste und deren Bereitschaft eine bestimmte Unterkunft zu mieten unklar. Um diese Forschungslücke zu füllen betrachtet diese Studie den Einfluss verschiedener Antwortstrategien im Rabmen eines experimentellen 

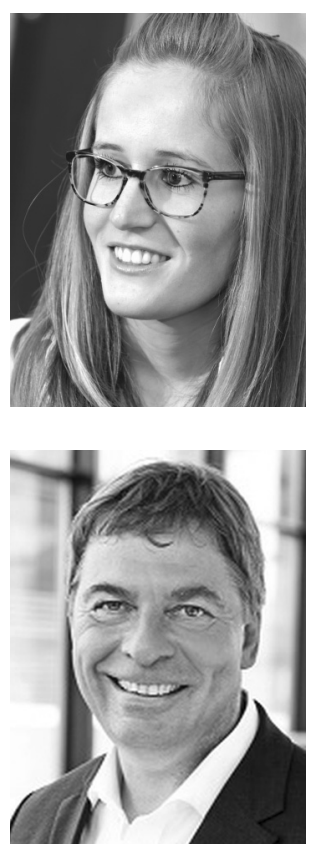

\section{Introduction}

The revolutionizing accomplishments of the "sharing economy" that allows to enjoy the bonuses of possession without the burden of responsibility and significant monetary investments (Botsman/ Rogers 2010; Hamari et al. 2013), have been particularly remarkable in the hospitality industry. Platforms like Airbnb, 9flats or Roomorama are transforming the industry landscape traditionally dominated by hotels. Particularly Airbnb has witnessed the most rampant growth since its launch in 2007, boasting 4 million guests, presence in 190+ countries and 300000 listings in 2013 alone (Airbnb 2014). However, while the idea of staying in cheaper (than hotels) private apartments when travelling has indisputable advantages, this concept is not without its challenges. Specifically, while hotels are subject to significant regulation with regard to their facilities, furnishing and additional services, as reflected in their star system, peer-to-peer platforms do not enjoy the same type of information transparency. Thus the guests are kept in ignorance of the quality and safety of the suggested offerings. As a result, host's reputation emerges as a centrepiece of these platforms, and is often seen as "the secret sauce" driving consumer decisionmaking and the scaling of the online markets (Stewart 2014).

Hence, as a part of their reputation system, platforms like Airbnb offer users a plethora of reputation-enhancing cues, including offline ID verifications, links to social media accounts of hosts and guests, verified photos and videos of the apartments and their owners, as well as an online review system (e.g. Airbnb 2014). In this environment of cues and hints, particularly reviews represent an important component of reputation-building efforts, as they have been consistently shown to be the most influential factor in consumer decisions for online marketplaces characterized by information asymmetry (Chatterjee 2001; McKnight et al. 2002a, 2002b). However, while all types of reviews may affect consumer choices, particularly negative reviews draw potential guests' attention and are under their constant scrutiny (Bambauer-Sachse/Mangold 2011). This phenomenon is known as the negativity bias (Vaish et al. 2008).

Recognizing the potentially ruinous effect of negative reviews on the reputation of the other party as well as the subjective nature of the travel experience judgements, platforms, like Airbnb, have readily embraced the "response" option. It empowers the accused party with the voice to challenge, to deny or at least to apologize for the subject of complaint. Indeed, past research from the areas of crisis communication (e.g. Lee/Song 2010) and ser- 
vice failure / recovery management (e.g. Munzel et al. 2012) offers some evidence that not only a review but also a response (if available) works to form public opinion, with some response strategies being more beneficial than others (Lee/Song 2010).

Nonetheless, little is known about the effectiveness of response in peer-to-peer sharing settings in general and on apartment sharing platforms in particular, which may partly explain the limited use of this functional tool. Gaining an insight into this area is, however, of considerable importance, since these findings can provide actionable recommendations for hosts and guests in their private reputation management. Against this background, this study utilizes experimental methods to get the understanding of the impact of the review negativity and different response strategies on the impression of the host and willingness to make a deal in peer-to-peer accommodation sharing settings. As such, these findings may enrich a currently scarce body of research on how users interact with reputation-enhancing cues in the new "sharing economy"- a novel direction of the human-centred stream of Social Media research.

\section{Related Work}

While a variety of mechanisms work to reveal the reputation of the unknown party in online marketplaces characterized by information asymmetry, online reviews remain the most prevalent and influential form for the assessment (Chatterjee 2001; McKnight et al. 2002a, 2002b). Presented as written evaluations of users' own experiences, reviews facilitate the selection of the best alternative as they guide consumer through the myriad of offers (Blal/Sturman 2014). Particularly in the hospitality industry, online reviews are extremely important, with users preferring feedback from other guests over the information posted by travel agencies (Chen/Xie 2008; Gretzel/Yoo 2008). However, while the impact of positive reviews is well-documented (Chevalier/Mayzlin 2006; Clemons et al. 2006), there is solid support for the special role of negative reviews in consumer decisions leveraged by the so-called "negativity bias" which is defined as "the propensity to attend to, learn from, and use negative information far more than positive information" (Vaish et.al. 2008, 383). Indeed, research confirms the unfavourable impact of negative online reviews on product attitude and, thereby, on purchasing intentions (Lee et al. 2008; Vermeulen/ Seegers 2009), and, as a consequence, on sales (Liu 2006; Vermeulen/Seegers 2009) and revenue (Cabral/Hortaçsu 2010). Particularly for the apartment sharing platforms, like Airbnb or 9 flats, the impact of negative reviews might be critical: since most feedback provided on these platforms is mostly positive, negative reviews stand out and, therefore, might be particularly scrutinized by the potential guests (Bambauer-Sachse/Mangold 2011; Park/Lee 2009). Hence, considering their potential significance, this paper focuses on the impact of the negative reviews in peer-to-peer accommodation sharing settings.

Recognizing the importance of reviews in ultimate consumer choices, online marketplaces increasingly empower the reviewed party with the "response" option, which may be used as a channel to challenge negative, unfair or otherwise undesirable feedback in the review systems. For example, such platforms as Airbnb, Yelp, and TripAdvisor do not only enable response function but also publish guidelines on how to respond to reviews. Also scholarly research provides some empirical evidence that not only reviews but also response and especially its specific type matter (Munzel et al. 2012). For example, the presence of an accommodative response to a negative review has been shown to have a greater favourable impact on consumers' evaluation of the company when compared to the defen- 
sive response or the absence thereof (Lee/Song 2010). However, despite the potential importance of response in the case of online review systems, research is this area still remains limited, with existing studies largely drawing on the evidence from related fields, such as crisis communication (e.g. Lee/Song 2010) and service failure / recovery management (e.g. Munzel et al. 2012).

In this context, the notion of the attribution of responsibility emerges as particularly relevant, coming across multiple studies on responses to negative eWOM (Lee/Song 2010), crisis communication (Coombs 1998, 2006) and service recovery/failure (Bitner 1990). Specifically, an unpleasant incident (the subject of the negative review) can be "attributed to external causes that are either uncontrollable ("The flight was delayed because of a blinding snowstorm") or controllable ("The personnel are poorly trained so that boarding takes forever"), with controllable causes being more detrimental (Weiner 2000, 384). Indeed, if individuals believe that the crisis situation was controllable, they will be more dissatisfied than in the case of non-controllable incidents (Bitner 1990). By offering an explanation to the incident, a company tries to alter attribution perceptions (Coombs/Holladay 1996). This is also relevant to the context of our study: negative online reviews are examples of expressed dissatisfaction and responses to negative reviews can be seen as attempts to provide explanations after a complaint. Discussing the role of attribution theory in consumer behaviour, Weiner (2000) identifies three strategies that a company can use for impression management after consumer has expressed product dissatisfaction, namely (1) denial, (2) excuse and (3) confession / apology. By relying on the (1) denial strategy a company is trying to refute the occurrence of any negative event. At the same time, the use of the (2) excuse strategy implies the provision of explanations about uncontrollable causes of the incident. Finally, (3) the confession/apology strategy presumes a pardon by an accused party and an offer of restitution. Considering the theoretical relevance, we concentrate our study on exploring the role of these three strategies for complaints with a high and a low degree of control by the accused party.

\section{Methodology}

\subsection{Hypotheses}

In order to find out the landscape of reviews and responses in the peer-to-peer accommodation sharing context, we conducted an exploratory study using private room listings from one popular peer-to-peer platform. Considering two popular touristic destinations, 82 listings in New York and 200 listings in Milan were singled out for further analysis and a total amount of 5708 reviews related to these listings were screened.

\subsubsection{Negative Valence of the Review}

Negative reviews are known for having a negative impact on consumers' attitudes (e.g. Lee et al. 2008). In the service failure context, the problem severity has been linked to the lower customer satisfaction and purchase intentions (Conlon/Murray 1996; Smith et al. 1999). Additionally, the judgment of responsibility may also be positively linked to the severity of the event (Coombs 2006; Lee 2005), thus worsening the image perceptions (Coombs 1998), impression and trust towards the organization (De Blasio/Veal 2009; Lee 2005). Similarly, in the peer-to-peer accommodation sharing settings, it is expected that strongly negative reviews will have a negative impact on the general impression of the host 
and the willingness to rent the room. For example, a negative review like: "I was disappointed that the photos provided did not represent the room that I was given. It was smaller, had bare walls, a small bookshelf, a nightstand, and a small table with a tiny desk chair" (Airbnb 2014) is unlikely to contribute positive impression of the host as it may imply a certain level of misrepresentation and, hence, dishonesty which damages the image (Goldstein 2015). All in all, we hypothesize that:

H1. Review negativity is negatively associated with the impression of the host (H1a) and the willingness to rent the room (H1b).

\subsubsection{Response Strategy: Confession / Apology}

Various studies have shown the effectiveness of apologetic responses in terms of attitudes towards the company, as compared to other less accommodative strategies (e.g. Conlon/ Murray 1996; Lee/Song 2010). For example, in the context of online complaints it has been demonstrated that accommodative responses, namely a combination of apology and compensation offer, result in more positive attitudes towards the company as opposed to defensive reaction or lack of response (Lee/Song 2010). This may be partly due to the special role of apology as it transmits "a good person committed a bad act" message to the consumers thus helping to soften a conflict situation (Weiner 2000, 386). Moreover, based on the empirical data, Munzel et al. (2012) suggest it is better to apologize even if the company is not responsible for the incident. Taken together, we argue that:

H2. Compared to the absence of response, apologetic response will have a positive impact on the impression of the host $(\mathrm{H} 2 \mathrm{a})$ and the willingness to rent the room $(\mathrm{H} 2 \mathrm{~b})$.

\subsubsection{Response Strategy: Denial}

Based on our pre-study we observe that denial is a frequently used response strategy in the context of peer-to-peer accommodation sharing platforms. Hosts deny the existence of the issues either directly by expressing it through "I do not agree", "It is not true" or indirectly by providing counter-arguments and showing the situation was different from how the guest described it. For example, one guest argued: "to let information not true, is never correct! my home is far from the metro station " ca granda " only 2/3 minutes walking, and not 10 minutes!" (Airbnb 2014). While some studies show a positive impact of this strategy in specific settings (e.g. Van Laer/de Ruyter 2010), there is a growing body of research refuting this view. For example, De Blasio/Veal (2009) find that denial results in lower scores of the impression of the organization, compared to excuse, no comment, apology and correction strategies. Moreover, Lee/Song (2010) show that exposure to the online critique coupled with a defensive response is more likely to lead observers to the conclusion that the company was responsible for the incident. In a complimentary finding, Lee (2005) reveals that by demonstrating responsibility with the help of the accepting response an organization is eventually blamed less for the crisis. Taken together we argue that:

H3: Compared to the absence of response, denial has a negative impact on the impression of the host ( $\mathrm{H} 3 \mathrm{a})$ and the willingness to rent the room $(\mathrm{H} 3 \mathrm{~b})$. 


\subsubsection{Response Strategy: Excuse}

Using the excuse strategy, a company introduces uncontrollable causes of the event in question as an explanation for what has happened (Weiner 2000), thereby distancing itself from the responsibility for the incident or denying its own responsibility when shifting the blame to a third party (Coombs 2006; Garrett et al. 1989). As an excuse is aimed to limit perceptions of responsibility (Coombs 2006), and perceptions of responsibility are in turn negatively related to impression and trust to organization (De Blasio/Veal 2009; Lee 2005), one can assume that a successful excuse would also have a positive impact on impression perceptions in the context of peer-to-peer accommodation sharing platforms. For example, making use of this strategy in response to a complaint, one Airbnb host has argued: "It's true, that Sunday the whole building was left without central heating for a few hours due to a breakdown of the heater, so it was quite cold!! Although it wasn't our fault, we felt very sorry...” (Airbnb 2014). In this case a plausible excuse that may work to limit the damage resulting from the negative feedback. Hence, we hypothesize that:

H4. Compared to the absence of response, excuse has a positive impact on the impression of the host $(\mathrm{H} 4 \mathrm{a})$ and the willingness to rent the room $(\mathrm{H} 4 \mathrm{~b})$.

\subsection{Experiment Design and Flow}

To determine the impact of different response strategies on general impression and willingness to rent, laboratory $2 \times 4 \times 2$ experiment was designed, in which review negativity (moderate vs. strongly negative), response strategy (confession/apology, denial, excuse, no response) and the context ("high control" vs. "low control") were manipulated. Considering a well-established role of control in interpreting complaints in such settings (Coombs 2007a, 2007b), the hypotheses were tested for two contexts that varied with regard to the controllability of the subject of complaint. Specifically, in the "high control" context a negative review about cleanliness of the room was provided. The "low control" context focused on the location of the apartment - a concern obviously beyond the influence of the host. Treatment conditions were formulated on the basis of existing reviews and responses of the actual guests and hosts collected in the pre-study, and were pre-tested with 16 subjects. Necessary adjustments to improve contrasts were made based on the elicited feedback.
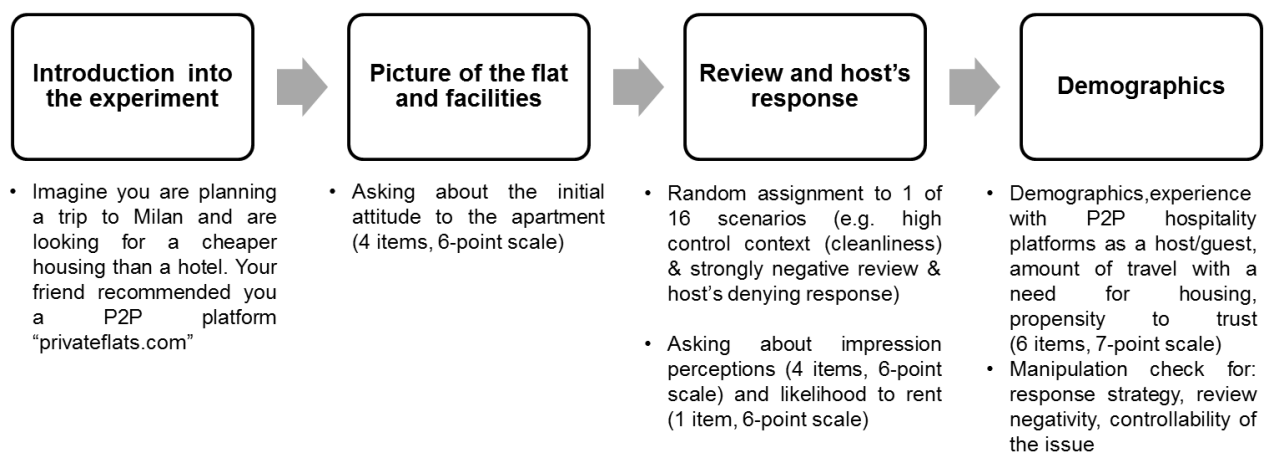

Figure 1: Workflow of the experiment 
First, upon accessing the survey participants were asked to imagine that they were planning a weekend trip to Milan and were looking for a room in an apartment as a cheaper alternative to a hotel. A fake platform name "privateflats.com" was used to avoid any reputation bias of the existing market players.

In the second step, respondents were presented with a picture and a description of a room (including its key attributes) similar to the way it is done on Airbnb.com or 9flats.com. Price and other attributes were chosen on the basis of the pre-study for Milan, in which average levels and the most frequent attributes of room description were derived. For example, our analysis has shown that $59 \%$ of all private room hosts in Milan in our pre-study sample are women, thus a female was presented as a host. To eliminate the effects of unusual spikes, the median price per night and per person (including service as well as a cleaning fee) among all listings was taken in the respective currency and comprised 56 Euro, since the study was subsequently conducted in Germany. Further, the icons "kitchen", "heating", "air-condition" and "essentials" (e.g. towels, bed linen, soap and toilet paper) were presented on the profile screen, since they were frequently mentioned amenities in our pre-study sample. The photos of the apartment were shot privately.

Presented with the picture of the accommodation, respondents were asked at once to express their initial attitude to the apartment (based on Barki/Hartwick 1994) by evaluating the following statements on a 6 -point scale ( 1 =strongly disagree, $6=$ strongly agree): I like the room; I think the room is worth considering; I could imagine staying in this room; Price-value relationship for the room meets my expectations. The attitude to the apartment was subsequently used as a control variable to account for a primary impression of the presented offer.

\section{Reviews from guests}

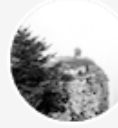

Alex

I was extremely dissatisfied with cleanliness of the room I stayed in. It was dirty, a lot of dust. It seems like it hasn't been cleaned before my arrival. Also the bathroom wasn't really clean at all, and the bed linen did not appear super fresh.

Response from host Andrea:

I do not agree with what you've written. The apartment got cleaned prior to your arrival, bed-linen was washed. No one before has ever complained about this. I find your complaint completely unwarranted.

Figure 2: Example of experimental treatment ("high-control" context "cleanness" $\mathrm{x}$ strongly negative review $\mathrm{x}$ denial as a response strategy)

In the third step, participants were randomly assigned into one of 16 treatment conditions ( 2 contexts: 2 negativity levels $x 4$ response strategies), i.e. between-subjects design was employed (see Table 1 and an example in Figure 2). 


\begin{tabular}{|c|c|c|c|c|}
\hline & \multicolumn{4}{|c|}{ Level of control $x$ Negativity level of the review } \\
\hline & \multicolumn{2}{|c|}{ Cleanliness (high control) } & \multicolumn{2}{|c|}{ Location (low control) } \\
\hline & strong negativity & moderate negativity & strong negativity & moderate negativity \\
\hline & $\begin{array}{l}\text { I was extremely dis- } \\
\text { satisfied with clean- } \\
\text { liness of the room I } \\
\text { stayed in. It was } \\
\text { dirty, a lot of dust. It } \\
\text { seems like it hasn't } \\
\text { been cleaned before } \\
\text { my arrival. Also the } \\
\text { bathroom wasn't re- } \\
\text { ally clean at all, and } \\
\text { the bed linen did not } \\
\text { appear super fresh. }\end{array}$ & $\begin{array}{l}\text { I was a bit dissatisfied } \\
\text { with cleanliness of the } \\
\text { room I stayed in. The } \\
\text { room was ok but not } \\
\text { sparkling clean, some } \\
\text { dust here and there, I } \\
\text { also found some hairs } \\
\text { in the bathroom. It } \\
\text { seems like it has been } \\
\text { cleaned before my ar- } \\
\text { rival, but it could have } \\
\text { been done better. I also } \\
\text { was not impressed by } \\
\text { the bed linen - it } \\
\text { seemed ok, but not } \\
\text { "crispy" clean. }\end{array}$ & $\begin{array}{l}\text { I was extremely dis- } \\
\text { satisfied with the loca- } \\
\text { tion. The apartment is } \\
\text { located really badly. It } \\
\text { really bothered me } \\
\text { that it is too far from } \\
\text { the city center and } \\
\text { any touristic attrac- } \\
\text { tions. Moreover, the } \\
\text { connection to the city } \\
\text { center by public trans- } \\
\text { port is really bad - it } \\
\text { took me very long to } \\
\text { get to where I wanted. }\end{array}$ & $\begin{array}{l}\text { I was a bit dissatisfied } \\
\text { with the location of the } \\
\text { apartment. The loca- } \\
\text { tion of the apartment is } \\
\text { ok, but not perfect. It } \\
\text { is a bit far from the } \\
\text { center and some touris- } \\
\text { tic attractions. Also, } \\
\text { the connection to the } \\
\text { city center by public } \\
\text { transport works, but } \\
\text { could be better. }\end{array}$ \\
\hline \multicolumn{5}{|c|}{ Response Strategies } \\
\hline $\begin{array}{l}\text { Confession/ } \\
\text { Apology }\end{array}$ & \multicolumn{2}{|c|}{$\begin{array}{l}\text { I apologize that you have experienced your } \\
\text { stay like this. I have paid close attention to } \\
\text { your comments and I will do my best to make } \\
\text { sure that the apartment is cleaned just before } \\
\text { the arrival of the guest so that no one experi- } \\
\text { ences anything like this again. }\end{array}$} & \multicolumn{2}{|c|}{$\begin{array}{l}\text { I apologize that you have experienced your stay } \\
\text { like this. I have paid close attention to your } \\
\text { comments and I will do my best to provide } \\
\text { guests with a better and clear description how } \\
\text { to easily reach the city center and all important } \\
\text { sights so that no one experiences anything like } \\
\text { this again. }\end{array}$} \\
\hline Excuse & \multicolumn{2}{|c|}{$\begin{array}{l}\text { Before your arrival I have hired a new cleaning } \\
\text { lady, and she was responsible for keeping the } \\
\text { apartment clean. I assume she has not cleaned } \\
\text { the apartment properly enough. There was } \\
\text { nothing I could have done about this situation. }\end{array}$} & \multicolumn{2}{|c|}{$\begin{array}{l}\text { Usually there is no problem with transportation } \\
\text { and one can easily reach the city center by regu- } \\
\text { lar public transport. However, during your stay } \\
\text { there were strikes in the Italian public transport } \\
\text { company, which may have caused these prob- } \\
\text { lems. There was nothing I could have done } \\
\text { about this situation. }\end{array}$} \\
\hline Denial & \multicolumn{2}{|c|}{$\begin{array}{l}\text { I do not agree with what you've written. } \\
\text { The apartment got cleaned prior to your ar- } \\
\text { rival, bed-linen was washed. No one before } \\
\text { has ever complained about this. I find your } \\
\text { complaint completely unwarranted. }\end{array}$} & \multicolumn{2}{|c|}{$\begin{array}{l}\text { I do not agree with what you've written. } \\
\text { It is a good location and no one before com- } \\
\text { plained about it. In fact, you can easily reach } \\
\text { city center and sights by regular public trans- } \\
\text { port. I find your complaint completely unwar- } \\
\text { ranted. }\end{array}$} \\
\hline $\begin{array}{l}\text { No } \\
\text { response }\end{array}$ & \multicolumn{2}{|l|}{ No response provided } & \multicolumn{2}{|l|}{ No response provided } \\
\hline
\end{tabular}

Table 1: Experimental conditions: 2 levels of review negativity x 2 levels of control x 4 response strategies

Here, respondents had to assess their general impression of the host with 4 questions on a 6-point scale ( $1=$ strongly disagree, $6=$ strongly agree): My impression of the host is positive; I like the host; The host's overall image is favorable to me; I am enthusiastic about the host. Then and the willingness to rent the offered room was assessed by answering: "How likely are you to rent the room from this host?" (scale: $1=$ very unlikely, $6=$ very likely). Finally, control variables were measured and manipulation checks were done. 


\subsection{Sampling}

Survey participants were recruited through the mailing list of a large German university in Fall 2014. As an incentive, 10 Amazon.de gift cards (€5 value) were raffled. A total of 545 respondents accessed our online survey, out of which 371 have completed it. Next, 3 observations with session duration less than 5 minutes were dropped. Finally, several observations did not pass one or several manipulation checks and, therefore, were dropped: 33 participants who were assigned to the "strongly negative" review found it "not at all" negative; and 19 participants failed to identify the strategy of the host's response. Hence, a final net sample includes 320 respondents.

$71 \%$ of the respondents in our sample are female; $30 \%$ of participants have claimed experience as a guest when using peer-to-peer accommodation services, but only $3.8 \%$ have tried themselves in the role of a host. Based on median values, an average respondent is 24 years old with a monthly income of 600-800 Euro, and has spent most life time in Germany. The sample consists to $89 \%$ of students, $52.5 \%$ have completed secondary education and $32.81 \%$ already have a bachelor degree.

\section{Results}

To ensure the reliability of further analysis, we checked the random assignment of participants across two settings, their understanding of strategies, review negativity and controllability degree for each context. First, Mann-Whitney tests revealed that the level of education $(z=-1.178$, Prob $>|z|=0.2390)$, study field $(z=1.157$, Prob $>|z|=0.2474)$, occupational status $(z=0.574$,Prob $>|z|=0.5658)$, income $(z=-0.535$, Prob $>|z|=0.5926)$, country of living $(z=-1.353$, Prob $>|z|=0.1760)$, gender $(z=-0.158$, Prob $>|z|=0.8744)$, Airbnb experience as a guest $(z=-1.124$, Prob $>|z|=0.2609)$ and as a host $(z=-0.498$, Prob $>|z|$ $=0.6185$ ) did not differ significantly across "high control" (cleanliness) and "low control" (location) contexts. Further, no significant differences in initial attitude to the apartment (Prob $>\mathrm{F}=0.9290$ ) and trust propensity (Prob $>\mathrm{F}=0.9290$ ) have been found between participants, as suggested by ANOVA tests, thus confirming the effectiveness of the random assignment of subjects to the "high control" and "low control" treatments.

Second, to ensure the validity of received responses, several manipulation checks were performed (Zikmund et al. 2012). To test whether respondents discern different response strategies, they were asked to answer the following questions on a 6-point scale (1=not at all; $6=$ very much): "In the response to the review, the host tries to ...deny that any issues exist” for the denial strategy; “... blame someone/something else for the situation” for the excuse; and "...apologize for the situation" for the confession / apology strategy. For those who were assigned into "no response" strategy, this question bloc was omitted. Non-parametric Kruskal-Wallis tests, relevant to the ordinary nature of dependent variable, indicated statistically significant difference in answers between strategies for the denial $(p=0.0001)$; confession / apology $(p=0.0001)$ and excuse $(p=0.0001)$ conditions. This means, for example, respondents assigned to the "denial" condition had stronger beliefs that the host was trying to "deny that any issues exist" than in other conditions. Taken together, this suggests that participants perceived treatment condition correctly.

Next, to ensure participants perceive the controllability of events correctly, two statements were offered: "The cause of the incident was in the control of the host" and "The cause of the incident could have been prevented by the host", measured on a 6-point scale 
(1=Strongly Disagree, 6=Strongly Agree). Results of non-parametric Kruskal-Wallis test indicate that respondents perceived cleanliness issues to be more controllable $(\mathrm{p}=0.0001$ ) and preventable $(\mathrm{p}=0.0001)$, corroborating the effectiveness of this manipulation.

Finally, the manipulation of review negativity was tested by asking on a 5 -point scale whether the review was "not at all negative", "somewhat negative", "moderately negative", "very negative” or "extremely negative. Results yielded a significant effect of negativity manipulation $(\mathrm{p}=0.0001)$. Taken together, respondents were able to distinguish between moderate and strongly negative review as well as between various strategies, and consider cleanliness issues to be more in host's control than location, suggesting that the relationships of interest could be further examined.

To evaluate the relative contribution of different strategies to the impression of the host and willingness to rent a room, OLS regressions were estimated for two corresponding contexts (see Table 2, Table 3).

\begin{tabular}{|c|c|c|c|c|c|}
\hline \multirow[b]{2}{*}{$\begin{array}{l}\text { Independent } \\
\text { Variables }\end{array}$} & \multicolumn{2}{|c|}{$\begin{array}{c}\text { "High control" } \\
\text { (cleanliness), } N=165\end{array}$} & \multicolumn{2}{|c|}{$\begin{array}{c}\text { "Low control" } \\
\text { (location), } \mathrm{N}=144\end{array}$} & \multirow{2}{*}{ Hypotheses } \\
\hline & $\operatorname{Beta}(\beta)$ & $\begin{array}{l}\text { Beta } \\
\text { stand. (b) }\end{array}$ & $\operatorname{Beta}(\beta)$ & $\begin{array}{l}\text { Beta } \\
\text { stand. (b) }\end{array}$ & \\
\hline Negativity of the review (H1a) & $-0.56 * * *$ & -0.29 & -0.15 & -0.08 & $\begin{array}{l}\text { Partly } \\
\text { supported }\end{array}$ \\
\hline Confession / Apology (H2a) & $0.72 * * *$ & 0.31 & $0.84 * * *$ & 0.39 & Supported \\
\hline Denial (H3a) & 0.24 & 0.11 & -0.12 & -0.06 & Rejected \\
\hline Excuse $(\mathrm{H} 4 \mathrm{a})$ & -0.10 & -0.05 & $0.56^{* *}$ & 0.27 & $\begin{array}{l}\text { Partly } \\
\text { supported }\end{array}$ \\
\hline Initial attitude to the apartment & $0.28 * * *$ & 0.32 & $0.28 * * *$ & 0.29 & \\
\hline Propensity to trust & -0.04 & -0.03 & $0.18 * *$ & 0.16 & \\
\hline Airbnb experience as a guest & $-0.41 *$ & -0.19 & 0.01 & 0.01 & \\
\hline Airbnb experience as a host & 0.36 & 0.07 & 0.41 & 0.09 & \\
\hline Income & $0.06^{*}$ & 0.14 & 0.00 & 0.00 & \\
\hline $\begin{array}{l}\text { Amount of travel with a need for } \\
\text { housing }\end{array}$ & -0.04 & -0.06 & $-0.15 *$ & -0.20 & \\
\hline Male & 0.17 & 0.08 & 0.09 & 0.05 & \\
\hline Age & -0.02 & -0.09 & 0.03 & 0.13 & \\
\hline \multirow[t]{3}{*}{ Country } & 0.12 & 0.03 & -0.01 & 0.00 & \\
\hline & \multicolumn{2}{|c|}{ R-squared $=0.3240$} & \multicolumn{2}{|c|}{ R-squared=0.3949 } & \\
\hline & \multicolumn{2}{|c|}{ Adj R-squared $=0.2658$} & \multicolumn{2}{|c|}{ Adj R-squared=0.3344 } & \\
\hline
\end{tabular}

Note: significant at $* * * 0.001 ; * * 0.05 ; *<0.1$ level

Table 2: Regression results with impression of the host as a dependent variable

We find that the review negativity has a detrimental influence on the impression of the host $(\beta=-0.56, p<0.001)$ and the willingness to rent a room $(\beta=-0.41, p<0.05)$ only in the "high control" (cleanliness) context. In terms of strategies, confession / apology significantly enhances the impression of the host in both "high control" $(\beta=0.72, p<0.001)$ and "low control" treatments $(\beta=0.84, p<0.001)$, compared to the situation when no response 
is provided. Apologetic response also promotes the willingness to rent a room independent of the context, with $\beta=0.57, \mathrm{p}<0.05$ for "high control" and $\beta=0.76, \mathrm{p}<0.001$ for "low control" scenarios. However, standardized betas suggest the contribution of confession / apology to the image perception after the "low control" event is slightly higher $(b=0.39)$ than in the "high control" context $(b=0.31)$. The same holds for the willingness to rent a room ( $b=0.30$ for "low control" and $b=0.20$ for "high control" treatment). Furthermore, excuse has a positive significant influence on the impression of the host $(\beta=0.56, p<0.05)$ and willingness to rent a room $(\beta=0.55, \mathrm{p}<0.001)$ only in the "low control" scenario. For the "high control" context, no significant effect of the excuse strategy was found. Denial has no effect independent of the treatment.

\begin{tabular}{|c|c|c|c|c|c|}
\hline \multirow{2}{*}{$\begin{array}{l}\text { Independent } \\
\text { Variables }\end{array}$} & \multicolumn{2}{|c|}{$\begin{array}{c}\text { "High control" } \\
\text { (cleanliness), } \mathrm{N}=165\end{array}$} & \multicolumn{2}{|c|}{$\begin{array}{l}\text { "Low control" } \\
\text { (location), } \mathrm{N}=144\end{array}$} & \multirow{2}{*}{ Hypotheses } \\
\hline & Beta $(\beta)$ & $\begin{array}{c}\text { Beta } \\
\text { Stand. (b) }\end{array}$ & Beta $(\beta)$ & $\begin{array}{c}\text { Beta } \\
\text { Stand. (b) }\end{array}$ & \\
\hline Negativity of the review $(\mathrm{H} 1 \mathrm{~b})$ & $-0.41 * *$ & -0.17 & -0.12 & -0.0014 & $\begin{array}{l}\text { Partly } \\
\text { supported }\end{array}$ \\
\hline Confession / Apology (H2b) & $0.57 * *$ & 0.20 & $0.76^{* * *}$ & 0.30 & Supported \\
\hline Denial (H3b) & 0.28 & 0.10 & -0.08 & 0.09 & Rejected \\
\hline Excuse $(\mathrm{H} 4 \mathrm{~b})$ & -0.31 & -0.12 & $0.55 * * *$ & 0.26 & $\begin{array}{l}\text { Partly } \\
\text { supported }\end{array}$ \\
\hline Initial attitude to the apartment & $0.59 * * *$ & 0.54 & $0.18 * * *$ & 0.38 & \\
\hline Propensity to trust & 0.00 & 0.00 & $0.17 * *$ & 0.15 & \\
\hline Airbnb experience as a guest & $-0.34 *$ & -0.13 & 0.15 & -0.08 & \\
\hline Airbnb experience as a host & -0.03 & 0.00 & 0.45 & -0.01 & \\
\hline Income & 0.01 & 0.03 & 0.01 & -0.04 & \\
\hline $\begin{array}{l}\text { Amount of travel with a need for } \\
\text { housing }\end{array}$ & -0.08 & -0.08 & $-0.12 * *$ & -0.15 & \\
\hline Male & 0.10 & 0.04 & -0.02 & 0.12 & \\
\hline Age & 0.00 & 0.00 & 0.01 & 0.05 & \\
\hline \multirow[t]{3}{*}{ Country } & 0.17 & 0.04 & 0.12 & 0.01 & \\
\hline & \multicolumn{2}{|c|}{ R-squared $=0.4181$} & \multicolumn{2}{|c|}{ R-squared $=0.3424$} & \\
\hline & \multicolumn{2}{|c|}{ Adj R-squared $=0.3667$} & \multicolumn{2}{|c|}{ Adj R-squared $=0.2762$} & \\
\hline
\end{tabular}

Note: significant at $* * * 0.001 ; * * 0.05 ; *<0.1$ level

Table 3: Regression results with willingness to rent a room as a dependent variable

As an extension of our results, we additionally analysed the average impression of the host and willingness to rent a room under different treatments. As illustrated in Figure 3, in case of the strongly negative review after controllable incident, excuse strategy with explanations about uncontrollable causes of the event results in the worst impression of the host (mean $=2.18$ ). In this case, the absence of response creates better opinion about the host (mean $=2.57$ ). When the host denies the fact that undesirable event took place, respondents evaluate the host's reputation at 2.84, while apologetic response increases the average impression up to 3.18 . 
If the incident is beyond the host's control, the average impression of the room keeper is slightly higher for all response strategies, except denial. Interestingly, in case of low control blaming others for the incident seems to be effective and the average impression (mean $=3.44)$ is much higher than in high control scenario.

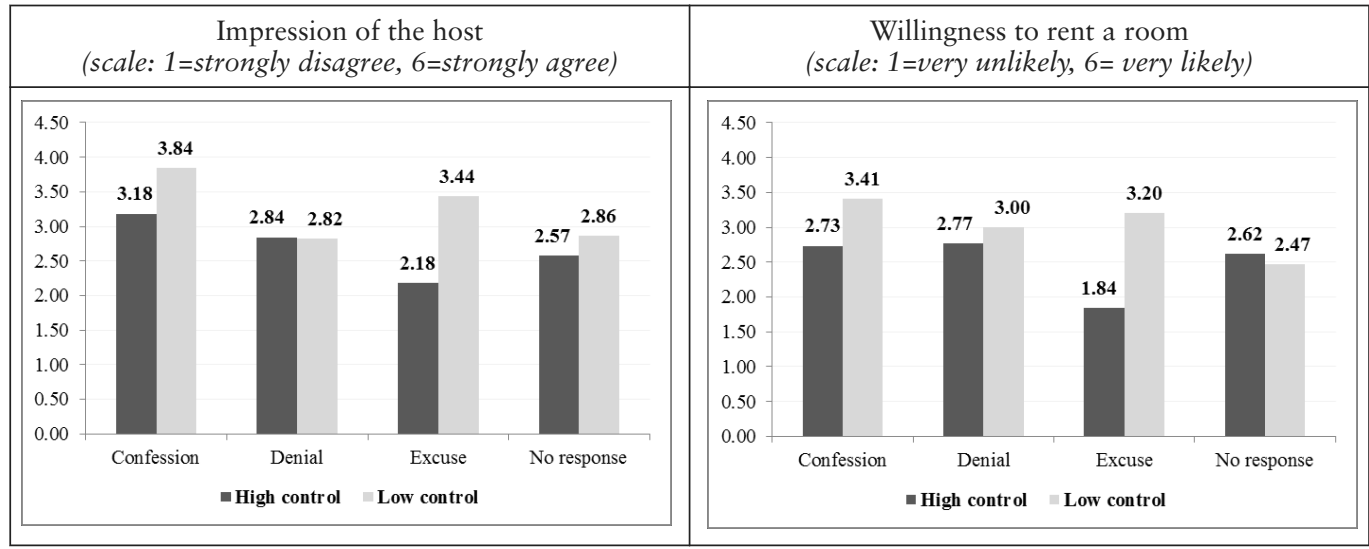

Figure 3: Mean values of "Impression of the host" and "Willingness to rent a room" when facing a strongly negative review and different response strategies

Regarding the willingness to rent a room, for the high control scenario confession (mean=2.73) or denial (2.77) strategy works out similarly. No response (mean=2.62) is the next best option, while after excuse the signing of the rent contract is very unlikely to happen (mean=1.84). However, when it comes to the uncontrollable event, excuse strategy seems to be successful as the average willingness to rent nearly doubles up to 3.20, while confession remains being the best solution (mean $=3.41$ ).

\section{Discussion and Managerial Implications}

This study focused on potential consumers (i.e. observers) of the sharing economy, on shaping their perceptions of the host's image and willingness to strike a bargain, resulted in a number of interesting findings and potentially substantive implications for online communication activities. In case of hospitality platforms like Airbnb or 9flats.com, where host's reputation appears to be a core transaction driver, this observer-oriented approach may be especially relevant, "considering the fact that an increasing number of potential consumers who have easy access to online complaints may be problematic to most companies" (Lee/Song 2010, 1079).

Contrary to the past research reporting the significant damaging influence of the review negativity on the product perception and buying intention (Lee et al. 2008; Vermeulen/ Seegers 2009), our study finds only partial support for this, evidencing the review negativity detriments the impression of the host $(\beta=-0.56, p<0.001)$ and the willingness to rent a room $(\beta=-0.41, p<0.05)$ only when the matter of complaint is controllable by the host, e.g. cleanliness of a room. When the reason of customer's dissatisfaction is not changeable by the host like location, no statistically significant impact is revealed. Possible reasons for that could be the fact that a customer roughly knows the location before booking and a 
host cannot improve it anyway. Therefore the tone of dissatisfaction is connected to the emotionality of the author of review, while in case of "cleanliness" higher review negativity may be attributed to higher severity of the problem.

Regression analysis suggests that for a potential customer who is intending to rent a room and faces review that contains negative information about cleanliness, writing an apologetic response may significantly improve the impression of the host and the willingness to make a deal, compared to no response option. Neither denial nor excuse is in this case better than ignoring the complaint. This implies that finding outside reasons for insufficient tidiness or denying the issue does not pay off as the majority of respondents do not find such behaviour convincing. Moreover, in the high control treatment, the significant influence of the "experience as a guest" is revealed on both the impression of the host $(\beta=-0.41, p<0.05)$ and the willingness to rent a room $(\beta=-0.34, p<0.1)$ suggesting that real participants of sharing economy are stricter and pickier customers.

When the subject of critic is hardly controllable by a host, e.g. location in our experiment, the analysis suggests that denial of the issue does not yield, while confession or excuse with attributing responsibility to a third party increases both dependent variables. However, the impact of the confession strategy is still higher compared to the excuse when forming judgement about the host ( $b=0.84$ vs. 0.56 ) or expressing willingness to rent $(b=0.76$ vs. 0.55$)$. This positive effect of the excuse which is originally considered to be a defensive strategy (Coombs 1998, 2006) could be explained by the fact that when the situation is perceived as non- or low- controllable by host, justifications about third party's fault are more readily accepted. Moreover, the credibility of an excuse can play a role, for instance in our study we had a strike in Italy as an excuse which sounds quite realistic.

Our findings have implications for IS practitioners including sharing economy participants, platforms and other affiliated stakeholders. Faced with a negative review, a service provider may neutralize it or turn to the own advantage. However, before responding one should first check whether the matter of complaint was controllable and avertible. If so, the only effective way to protect the image and purchase probability is to apologize for the incident. In case of an undesirable event beyond the service provider control both confession and excuse with attributing responsibility to a third party will improve the impression and purchase probability, as compared to the absence of response.

\section{Limitations and Opportunities for Future Research}

The paper revealed the influence of the review negativity and response strategies in the online peer-to-peer complaint context. These findings, however, should be interpreted with caution. First of all, the sample characteristics and size can be enlarged. Second, the study checked for three main response types according to Weiner (2000).

Taken together, this paper paves a way for further studies in the field of impression and reputation management. Conducting a larger experiment may imply a more fine-grained classification of response strategies, e.g. proposed by Coombs (2006, 2007). Moreover, mixed strategies should be explored when, for instance, a formal apology is present, but the responsibility is not admitted. Based on the recent evidence that discrete emotions like anxiety and anger influences the perceived helpfulness of online reviews (Yin et.al. 2014) one may assume style, grammar and emotional tone of the review have significant implications to the brand image. Finally, future studies need to consider the effect of consensus or 
discrepancy between different reviews (Lee/Song 2010; Lee/Cranage 2012) and responses as well as the author's credibility.

\section{References}

Airbnb (2014): URL: https://www.airbnb.com/annual/(visited on 11/26/2014)

Ba, S./Pavlou, P. (2002): Evidence of the effect of trust building technology in electronic markets: Price premium and buyer, in: MIS Quarterly 26 (3), 243-268.

Bambauer-Sachse, S./Mangold, S. (2011): Brand equity dilution through negative online word-ofmouth communication, in Journal of Retailing and Consumer Services 18 (1), 38-45.

Barki H./Hartwick, J. (1994): Measuring User Participation, User Involvement, and User Attitude, in: MIS Quarterly 18 (1), 59-82.

Benoit, W. L. (1997): Image repair discourse and crisis communication, in: Public Relations Review 23 (2), 177-186.

Bitner, M. J. (1990): Evaluating service encounters: The effects of physical surroundings and employee responses, in: Journal of Marketing 54 (2), 69-82.

Blal, I./Sturman, M. (2014): The differential effects of the quality and quantity of online reviews on hotel room sales, in: Cornell Hospitality Quarterly 55 (4), 365-375.

Botsman, R./Rogers, R. (2010): Beyond Zipcar: Collaborative Consumption, in: Harvard Business Review 88(10), 30-30.

Cabral, L./Hortaçsu, A. (2010): The dynamics of seller reputation: Evidence from eBay, in: The Journal of Industrial Economics 58 (1), 54-78.

Chatterjee, P. (2001): Online reviews: Do consumers use them?, in: Advances in Consumer Research 28, 129-133.

Chen, Y./Xie J. (2008): Online consumer review: Word-of-mouth as a new element of marketing communication mix, in: Management Science 54 (3), 477-491.

Chevalier, J. A./Mayzlin, D. (2006): The effect of word of mouth on sales: Online book reviews, in: Journal of Marketing Research 43 (3), 345-354.

Clemons, E. K./Gao, G./Hitt, L. M. (2006): When online reviews meet hyperdifferentiation: A study of the craft beer industry, in: Journal of Management Information Systems 23 (2), 149-171.

Conlon, D. E./Murray, N. M. (1996): Customer perceptions of corporate responses to product complaints: The role of explanations, in: Academy of Management Journal 39 (4), 1040-1056.

Coombs, W. T. (1998): An analytic framework for crisis situations: Better responses from a better understanding of the situation, in: Journal of Public Relations Research 10 (3), 177-191.

Coombs, W. T. (2006): The protective powers of crisis response strategies: Managing reputational assets during a crisis, in: Journal of Promotion Management 12 (3-4), 241-260.

Coombs, W. T. (2007a): Attribution theory as a guide for post-crisis communication research, in: Public Relation Review 33 (2), 135-139.

Coombs, W. T. (2007b): Protecting organization reputations during a crisis: The development and application of situational crisis communication theory, in: Corporate Reputation Review 10 (3), 163-176.

Coombs, W. T./Holladay, S. J. (1996): Communication and attributions in a crisis: An experimental study in crisis communication, in: Journal of Public Relations Research 8 (4), 279-295.

De Blasio, A./Veale, R. (2009): Why say sorry? Influencing consumer perceptions post organizational crises, in: Australasian Marketing Journal 17 (2), 75-83. 
De Lecaros-Aquise, X. (2014): The rise of collaborative consumption and the experience economy. URL : http://www.theguardian.com/technology/2014/jan/03/collaborative-consumption-experience-economy-startups (visited on 11/25/2014).

Edelman, B. G./Luca, M. (2014): Digital discrimination: The case of Airbnb.com, in: HBS Working Paper Number: 14-054, Harvard Business School.

Garrett, D. E./Bradford, J. L./Meyers, R. A./ Becker, J. (1989): Issues management and organizational accounts: An analysis of corporate responses to accusations of unethical business practices, in: Journal of Business Ethics 8 (7), 507-520.

Goldstein, G. (2015): Tips to Be a Great Host in the Sharing Economy. URL : http:// blog.storex.me/7-tips-to-be-a-great-host-in-the-sharing-economy/ (visited on 11/25/2015)

Gretzel, U./Yoo, K. (2008): Use and impact of online travel reviews, in: Information and communication technologies in tourism. Ed. by O'Connor, P., Höpken, W. and Gretzel, U. New York: Springer, 35-46.

Hamari, J./Sjöklint, M./Ukkonen, A. (2013): The Sharing Economy: Why People Participate in Collaborative Consumption, in: SSRN Working paper. URL: http://papers.ssrn.com/sol3/papers.cfm? abstract_id=2271971 (visited on 11/25/2014).

Landis, J. R./Koch, G. (1977): The measurement of observer agreement for categorical data, in: Biometrics 33(1), 159-174.

Lee, C./Cranage, D. (2012): Toward Understanding Consumer Processing of Negative Online Wordof-Mouth Communication: The Roles of Opinion Consensus and Organizational Response Strategies, in: Journal of Hospitality \& Tourism Research, 38 (3), 330-360.

Lee, B. K. (2005): Hong Kong consumers' evaluation in an airline crash: A path model analysis, in: Journal of Public Relations Research 17 (4), 363-391.

Lee, J./Park, D. H./Han, I. (2008): The effect of negative online consumer reviews on product attitude: An information processing view, in: Electronic Commerce Research and Applications 7 (3), 341-352.

Lee, Y. L./Song, S.(2010): An empirical investigation of electronic word-of-mouth: Informational motive and corporate response strategy, in: Computers in Human Behavior 26 (5), 1073-1090.

Liu, Y. (2006): Word of mouth for movies: Its dynamics and impact on box office revenue, in: Journal of Marketing 70 (3), 74-89.

McKnight, D. H./Choudhury, V./Kacmar, C. (2002a): The impact of initial consumer trust on intention to transact with a web site: A trust building model, in:Journal of Strategic Information Systems 11 (3), 297-323.

McKnight, D. H./Choudhury, V./Kacmar, C. (2002b): Developing and validating trust measures for e-commerce: An integrative typology, in: Information Systems Research 13 (3), 334-359.

Munzel, A./Kunz, W. H./Jahn, B. (2012): The power of saying sorry - insights on customer service in new media online channels, in: Proceedings of the $12^{\text {th }}$ International Research Conference in Service Management. May 29 - June 1, La Londe les Maures, France.

Nadler, S. (2014): The sharing economy: What is it and where is it going, in: Working Paper, Massachusetts Institute of Technology.

Park, C. L./Lee, T. M. (2009): Information direction, website reputation and eWOM effect: A moderating role of product type, in: Journal of Business Research 62 (1), 61-67.

Smith, A. K./Bolton, R. N./ Wagner, J. (1999): A model of customer satisfaction with service encounters involving failure and recovery, in: Journal of Marketing Research 36 (3), 356-372. 
Stewart, P. J. (2014): “Why Uber Should Let People See Their Own Passenger Ratings” URL: http:// www.businessinsider.com/reputation-and-the-sharing-economy-2014-10? IR=T (visited on 03/01/2015).

Vaish, A./Grossmann, T./Woodward, A.(2008): Not all emotions are created equal: The negativity bias in social-emotional development, in: Psychological Bulletin, 134(3), 383-403.

Vermeulen, I. E./Seegers, D. (2009): Tried and tested: The impact of online hotel reviews on consumer consideration.”, in: Tourism Management 30 (1), 123-127.

Weiner, B. (2000): Attributional thoughts about consumer behaviour, in: Journal of Consumer Research 27 (3), 382-387.

Yin, D./Bond, S./Han, Z. (2014): Anxious or Angry? Effects of Discrete Emotions on the Perceived Helpfulness of Online Reviews, in: MIS Quarterly 38 (2), 539-560.

Zikmund, W./Babin, B./Carr, J./Griffin, M. (2012): Business research methods, in: Cengage Learning.

Abramova, Olga, M. Sc., promoviert am Lehrstuhl für Wirtschaftsinformatik I Software Business \& Information Management der Technische Universität Darmstadt.

Anschrift: Technische Universität Darmstadt, Lehrstuhl für Wirtschaftsinformatik | Software Business \& Information Management, Hochschulstraße 1, 64289 Darmstadt, Tel.: +496151 16-2663, E-Mail: abramova@is.tu-darmstadt.de

Krasnova, Hanna, Prof. Dr., ist Professorin für Wirtschafts- und Verwaltungsinformatik, insb. datenintensive Anwendungen an der Universität Potsdam, Deutschland.

Anschrift: Universität Potsdam, Lehrstuhl für Wirtschaftsinformatik, insb. datenintensive Anwendungen, August-Bebel-Str. 89, 14482 Potsdam, Tel. +49 331/ 977-3379, E-Mail: krasnova@uni-potsdam.de

Shavanova, Tetiana, Universität Bern, Bern, Switzerland, tetiana.shavanova@students.unibe.ch

Fuhrer, Andrea, Universität Bern, Bern, Switzerland, andrea.fuhrer@students.unibe.ch

Buxmann, Peter, Prof. Dr., ist Professor für Wirtschaftsinformatik I Software Business \& Information Management an der Technische Universität Darmstadt.

Anschrift: Technische Universität Darmstadt, Lehrstuhl für Wirtschaftsinformatik I Software Business \& Information Management, Hochschulstraße 1, 64289 Darmstadt, Tel.: +49 6151 16-2663, E-Mail: buxmann@is.tu-darmstadt.de 